\title{
Recenzja \\ Paweł Kuczma, Lobbing $w$ Polsce, Dom Organizatora, Toruń 2010, ss. 267
}

Zjawisko lobbingu towarzyszy systemom demokratycznym i jest przejawem kreowania rzeczywistości przez społeczeństwo w sposób pośredni i jawny. Jest definiowane na wiele sposobów i analizowane przez badaczy kilku dziedzin nauki, jak: prawo, socjologia oraz politologia. Bywa różnie odbierane przez opinię publiczną. W państwach o ugruntowanym systemie demokratycznym lobbing postrzegany jest jako profesjonalne działanie na rzecz rozwiązań korzystnych, np. dla danej grupy społecznej lub zawodowej. Młode demokracje, w których obserwuje się niski poziom kultury politycznej i zaufania społecznego zjawisko lobbingu odbierane jest negatywnie ze względu na kojarzenie go z patologią władzy, np. z korupcją. Nieregulowana prawnie kwestia lobbingu sprawia, że lobbyści pozostają w szarej sferze działalności publicznej. Z tego względu, niektóre młode demokracje zdecydowały się na wprowadzenie odpowiednich ustaw. Należą do nich Gruzja, Litwa i Polska.

Książka Lobbing w Polsce, z wyeksponowaną płaszczyzną prawną wpisuje się w nurt analizy lobbingu podejmowanej w Polsce, zarówno przez ekspertów i badaczy akademickich, jak i polityków od połowy lat dziewięćdziesiątych. Postawiony przez Autora cel pracy (s. 8) został zrealizowany. W książce zaprezentował on uregulowania prawne lobbingu w Polsce oraz $w$ innych państwach. Poprzedził je zdefiniowaniem niezbędnych dla omawianej tematyki pojęć i przedstawieniem genezy problemu badawczego. Wskazał i przeanalizował proces instytucjonalizacji zjawiska lobbingu w Polsce (s. 181 185) i UE. Dodatkową zaletą publikacji są licznie zamieszczone przykłady lobbingu (s. 39, 45, 92), co sprawia, że książka dotycząca zagadnień prawniczych jest napisana lekkim językiem.

W recenzowanej publikacji został zastosowany układ problemowy. Praca składa się ze wstępu, pięciu rozdziałów, z których wydzielono podrozdziały oraz zakończenia. Tytuły poszczególnych części odzwierciedlają treści w nich opisane i przeanalizowane. Autor nie podaje wyraźnej cezury 
czasowej opisywanego zjawiska. Rozważania o genezie lobbingu rozpoczyna od starożytności, następnie przechodzi do XVIII i XIX wieku w USA oraz Wielkiej Brytanii. Zasadnicza część pracy dotyczy natomiast okresu od połowy lat 90. do roku wydania książki.

Treść recenzowanego opracowania zasadniczo jest logicznie przyporządkowana do rozdziałów, które sprawiają wrażenie równych pod względem objętości, poza ostatnim znacznie bardziej rozbudowanym. Jest to uzasadnione, ze względu na jego treść, dotyczącą uregulowań prawnych w Polsce stanowiącą zasadniczą część publikacji. Natomiast tytuł książki niezupełnie odzwierciedla jej treść. Polsce poświęcony został tylko jeden rozdział publikacji, zaś w czterech pozostałych równie często pojawiają się analizy dotyczące innych państw. Dodatkowo Autor wyraźnie zaznaczył, że celem książki była analiza kwestii normatywnych w kontekście lobbingu (s. 8), zaś tytuł sugeruje szersze ujęcie wskazanej tematyki.

We Wstępie Autor zasygnalizował prawną płaszczyznę prowadzonych analiz zjawiska lobbingu. Wskazał, że zainteresowanie badaną problematyką w Polsce rozpoczęło się w połowie lat dziewięćdziesiątych XX w. ${ }^{1}$ Zaznaczył, że analizowane zjawisko było postrzegane, jako charakterystyczne głównie dla państw anglosaskich. Przedstawione podejście do omawianego problemu szybko uległo zmianie. Związane to było z wykryciem kolejnych afer w okresie prac nad ustawą o działalności lobbingowej z 2005 r. Autor wskazał również cele drugorzędne. Należało do nich omówienie regulacji prawnych badanego zjawiska w innych państwach (USA, Gruzji, Litwy, Wielkiej Brytanii, Francji) oraz analiza problematyki instytucjonalizacji lobbingu i działania lobbystów w Polsce. Problemy poruszone w książce dotyczą głownie kwestii normatywnych, poczynając od regulaminów aż do ustaw lub omówienia przyczyn braku jakiejkolwiek regulacji np. w Rosji.

Ponadto Wstęp zawiera metody badawcze zastosowane $\mathrm{w}$ analizie zebranego materiały naukowego. Autor posługiwał sie głównie metodę badawczą charakterystyczną dla nauk prawnych, czyli metodą dogmatyczno-prawną. Ponadto zastosował metodę deskryptywną, przytaczając szereg definicji omawianego zjawiska i ilustrując analizowane normy prawne licznymi przykładami oraz historyczną dokonując genezy lobbingu i grup nacisku. Dodatkowo skorzystał z metody komparatystycznej w zestawianiu uregulowań

1 Zob. A. Kołodziejska, W. Bąba, Polski lobbing w Unii Europejskiej, „Zeszyty Naukowe Akademii Ekonomicznej w Krakowie” nr 701, 2006, s. 125-127. 
prawnych różnych państw. Zaczerpnął również z metody statystycznej przytaczając badania ankietowe prowadzone w Sejmie przez M. K. Milickiego.

Wstęp zawiera również krótką charakterystykę treści każdego z rozdziałów. Autor podkreślił, że książka jest nieco zmienioną wersją rozprawy doktorskiej obronionej na Uniwersytecie Wrocławskim w 2009 r.

W rozdziale pierwszym „Pojęcie i istota lobbingu” zostało przytoczonych i scharakteryzowanych szereg definicji i ujęć poruszanego zagadnienia (s. 22-31). Autor zamieścił terminy zaczerpnięte $\mathrm{z}$ nauk prawnych, politologicznych oraz socjologicznych. Wskazał różnice w zawartości części składowych różnych definicji odnosząc się do historii i doświadczeń poszczególnych państw, terminów zamieszczanych w słownikach i encyklopediach oraz przemyśleń badaczy istotnych dla omawianego zjawiska. Autor skoncentrował się na przedstawieniu definicji normatywnych wybranych państw. Nakreślił sytuację towarzyszącą tworzeniu uregulowań prawnych ze szczególnym podkreśleniem ustaw. Na wskazanym tle przedstawił definicje lobbingu utworzone w Polsce (s. 32-41).

W części drugiej „Podmioty lobbingu i metody ich oddziaływania” Autor szeroko charakteryzował lobbystów oraz grupy interesu (s. 44-61). Podkreślił, że w polskim prawie, mimo regulacji normatywnych, nadal brakuje definicji lobbysty, zaś grupy interesu pełniące rolę zleceniodawcy często identyfikowane są z grupami nacisku. Wymienił również potencjalnych adresatów działań lobbingowych $\mathrm{z}$ rozróżnieniem na tych ujętych $\mathrm{w}$ polskiej ustawie z 2005 r., czyli bezpośrednio wpływających na proces ustawodawczy oraz nieujętych enumeratywnie w przytoczonym akcie prawnym, jak np. władze na szczeblach samorządowym ${ }^{2}$. Autor wskazał też dwa rodzaje metod oddziaływania na decydentów ${ }^{3}$ (s. 77). Pierwsza $z$ nich to lobbing ofensywny opierający się na działaniach w kierunku zmiany istniejącej sytuacji oraz defensywny oparty w pracy nad zachowaniem status quo. Drugi podział dotyczył działań bezpośrednich, jak rozmowy, spotkania i pośrednich, czyli odwoływania się do autorytetów i opinii publicznej. Rozdział ten zawiera wiele przykładów prezentujących zarówno lobbystów, zleceniodawców, adresatów, jak i metody prowadzenia działań lobbingowych.

2 Por. A. Niżyńska, Studia przypadku lobbingu w województwie samorządowym, [w:] Lobbing w samorządzie województwa. Raport z badań i monitoringu, pod red. G. Markowskiego, Warszawa 2010, s. 89-107.

3 Zob. K. Jasiecki, M. Molęda-Zdziech, U. Kurczewska, Lobbing. Sztuka skutecznego wywierania wpływu, Kraków 2000, s. 112-135. 
„Organizacje pośredniczące $\mathrm{w}$ artykułowaniu interesów” to tytuł rozdziału trzeciego. Autor przeanalizował w nim głównie relacje zachodzące między grupami interesu a partiami politycznymi w kontekście działalności lobbingowej. Wymienił również szereg czynników determinujących aktywność lobby i skuteczność podejmowanych przez nie działań. Bezsprzecznie zaliczył do nich: system partyjny, wewnętrzną strukturę partii, funkcjonowanie zespołów parlamentarnych, kadencję parlamentu, kampanię wyborczą oraz finansowanie partii politycznych ${ }^{4}$ (s. 111 - 131).

Rozdział czwarty „Kształtowanie się lobbingu w regulacjach prawnych” rozpoczęły rozważania na temat genezy lobbingu. Autor przeanalizował zjawisko lobbingu począwszy od jego pierwszych przejawów w średniowieczu w Wielkiej Brytanii poprzez normy prawne w USA i we Francji zarejestrowane od XVIII wieku. Szczególnie zainteresował się on prawem petycji, wolnością zrzeszania się i wolnością zgromadzeń. Dużo uwagi poświęcił lobbingowi w UE. Przeanalizował kształtowanie podstaw prawnych, regulacje wewnątrzparlamentarne i te dotyczące Komisji Europejskiej. Autor omówił również definicje i kodeks postępowania eurolobbysty. W rozdziale tym przeanalizował również dwa modele lobbingu. Pierwszy - pluralistyczny, charakterystyczny dla krajów anglosaskich; drugi - korporacyjny, występujący w Europie Środkowo-Wschodniej.

Ostatni rozdział nosi tytuł „Polska regulacja prawa lobbingu”. Jest to zasadnicza część książki, znacznie rozbudowana w porównaniu do poprzednich. Autor przeanalizował prawnokonstytucyjne podstawy funkcjonowania lobbingu wskazując, że to zjawisko w polskiej konstytucji właściwie zostało pominięte. Prześledził proces powstawania ustawy dotyczącej lobbingu w Polsce ${ }^{6}$. Dokładnie przeanalizował Ustawę o działalności lobbingowej $\mathrm{w}$ procesie stanowienia prawa wskazując na takie zagadnienia, jak: rejestr lobbystów, program prac legislacyjnych, kontrolę zawodową działalności lobbingowej czy współpracowników deputowanych (s. 184-203). Opisał również proces legislacyjny oraz kodeks etyki zawodowej lobbysty w ujęciu polskim. Dokonał oceny zakresu i wagi ustawy oraz wskazał jej

4 Por. J. Podgórski, Umiejętności w profesjonalnym lobbingu, [w:] Lobbing w praktyce. Doświadczenia polskie, „Zeszyty Naukowe Collegium Civitas”, nr 7, 2006, s. 47 - 69.

5 Zob. M. M. Wiszowaty, Regulacja prawna lobbingu na świecie, Warszawa 2008, s. 65-72 .

6 Por. idem, Działalność lobbingowa w procesie stanowienia prawa, Warszawa 2010, s. 7-44. 
mankamenty np. brak definicji lobbysty, lub zbyt szeroki zakres terminologiczny samego pojęcia lobbing.

W Zakończeniu Autor zastanawiał się nad zasadnością wprowadzenia do polskiego ustawodawstwa ustawy dotyczącej lobbingu, dołączając ze swymi wątpliwościami do wielu innych badaczy omawianego zjawiska. Argumentował przeciw takiemu rozwiązaniu wyliczając niedociągnięcia powstałego aktu prawnego. Wskazał też na zalety i wady praktyk lobbingowych, których jakość uzależniona jest od wielu czynników, jak np. szeroko rozumiany poziom ugruntowania systemu demokratycznego.

Rozdziały i Zakończenie omawianej książki zostały napisane jasno i logicznie. Autor w poszczególnych rozdziałach oraz w Zakończeniu, gdzie zamieszczone zostały wnioski, używa narracji bezosobowej. Wyjątek stanowi Wstęp napisany w pierwszej osobie. Ponadto we wprowadzeniu zostało zamieszczone streszczenie poszczególnych rozdziałów, których ułożenie różni się od tego zapisanego w spisie treści. Mianowicie część trzecia książki we Wstępie została błędnie umieszczona, jako ostatnia, co spowodowało dalsze przesunięcia w numeracji. Wyjaśnieniem sytuacji zdaje się być fakt, że książka jest „nieco zmienioną wersją rozprawy doktorskiej” (s. 10) zaś owym zmianom nie zostało poddane streszczenie książki ani styl narracji we wprowadzeniu.

Książka opatrzona jest w spis treści jedynie w języku polskim, podobnie jest ze Wstępem oraz Zakończeniem. Nie posiada, poza nielicznymi wyjątkami, tabel i wykresów. Autor zamieścił obszerny wykaz literatury, w dużej mierze oparty na fragmentarycznych opracowaniach oraz artykułach prasowych i internetowych. Świadczyć to może o wypełnieniu przez recenzowaną książkę luki w literaturze tematu. W bibliografii liczącej ok. 350 publikacji, mimo odnoszenia się Autora do licznych przykładów z innych państw, skorzystał on z zaledwie 15 pozycji literatury obcojęzycznej.

Książka, mimo kilku uchybień, napisana jest lekkim językiem, bardzo interesująca i godna polecenia. Zawiera analizę normatywną zjawiska lobbingu w wybranych państwach, w UE i w Polsce. W stosunku do publikowanych wcześnie, głównie artykułów naukowych, opracowań eksperckich oraz książek z pogranicza prawnego ujęcia lobbingu Autor podjął udaną próbę całościowego ujęcia poruszanej problematyki badawczej. 